V. F. USHKALOV, T. F. MOKRII, I. YU. MALYSHEVA, N. V. BEZRUKAVYI

\title{
WEAR-RESISTANT WHEEL PROFILE FOR A FREIGHT CAR WITH AN INCREASED AXLE LOAD
}

\author{
Institute of Technical Mechanics \\ of the National Academy of Sciences of Ukraine and the State Space Agency of Ukraine \\ 15 Leshko-Popel St., Dnipro 49005, Ukraine; e-mail: Mokrii.T.F@nas.gov.ua
}

\begin{abstract}
At present, new 18-9817 (ICG Motion Control) trucks designed for $1520 \mathrm{~mm}$ railway freight cars with an axle load increased to $25 \mathrm{tf}$ are adopted for freight car fleet renewal in Ukraine. The aim of this paper is to develop a wear-resistant wheel profile for these trucks to improve wheel-rail interaction and contact conditions. To achieve this aim, use was made of methods of mathematical simulation, numerical integration, vibration theory, and statistical dynamics.

The paper presents the results of studies on the development of a wear-resistant wheel profile. A procedure of wheel profile selection out of a series of constructed profiles is described. For each candidate profile, the 3D problem of wheel-rail contact was solved, and wheel-rail interaction parameters, including the contact path dimensions and locations, were analyzed. A gondola car with 18-9817 trucks negotiating a narrow curve (of radius $300 \mathrm{~m}$ ) with different rail wear degrees and moving on a tangent track was calculated. Based on the analysis of the results obtained, a selection out of the constructed profiles was made by two contradictory criteria: a minimum of wheel flange wear and a maximum of car dynamic stability margin. The selected profile was named ITM-73-03.

It was shown that the new wheel profile considerably improves the process of increased axle load car - track interaction and significantly reduces wheel flange wear while offering high ride quality.

A possibility to use the ITM-73-03 wheel profile in trucks with a standard axle load of 23.5 tf was assessed. To do this, the vibrations of a gondola car with a new-generation 18-7020 trucks moving in curves and on a tangent track were calculated. The results demonstrated that the wheels of a freight cars with an axle load of 23.5 tf may be machined to the new profile too.
\end{abstract}

Keywords trucks of a freight car with an increased axle load, wheel wear, ride quality, development of a wear-resistant wheel profile.

1. Model 18-7020 type 2 two-axle truck. URL: http://test.kvsz.com/index.php/ru/produktsiya/ gruzovoe-vagonostroenie/khodovye-chasti/telezhki/item/833-dvukhosnaya-telezhka-model-18-7020.

2. 18-9817 two-axle truck with a 25 tf wheelset-to-rail load. URL: http://okb.at.ua/publ/telezhka_dvukhosnaja_modeli_18_9817_s_nagruzkoj_ot_kolesnoj_pary_na_relsy_25t/1-1$0-6$.

3. William J. H., Ebersöhn W., Lundgren J., Tournay H., Zakharov S. Guidelines to Best Practices for Heavy Haul Railway Operations: Wheel and Rail Interface Issues. USA: International Heavy Haul Association, 2001. $482 \mathrm{pp}$.

4. Ushkalov V. F., Mokrii T. F., Malysheva I. Yu., Bezrukavyi N. V. Improvement of the running gear of a prospective freight car (in Russian). Technical Mechanics. 2017. No.4. Pp. 79-88.

5. Ushkalov V. F., Mokrii T. F., Malysheva I. Yu. Mathematical model of railway vehicle - track interaction with account for the contact force distribution over the contact patches (in Russian). Tekhnicheskaya Mekhanika. 2015. No. 2. Pp. 79-89. 